\title{
Neuroprotective effects of Peltophorum (1) pterocarpum leaf extract against hydrogen peroxide induced oxidative stress and cytotoxicity
}

Theanmalar Masilamani ${ }^{1 *}$, Thavamanithevi Subramaniam ${ }^{1}$, Norshariza Nordin ${ }^{2}$ and Rozita Rosli

\begin{abstract}
Background: Peltophorum pterocarpum is a plant from the family of Leguminosae and a tropical tree found in South East Asia region. The leaves of the plant is rich in anti-oxidant polyphenols. Traditionally this plant was used to cure intestinal disorders and as a relief for sprain, bruise, muscular pain and sores and for pain during child birth. Since oxidative stress is a major contributing factor towards neurodegenerative diseases the leaves of this plant was explored for its neuroprotective properties.

Method: In this study, we report the neuroprotective properties of the ethanolic extract of Peltophorum pterocarpum leaf against oxidative stress induced cell death by $\mathrm{H}_{2} \mathrm{O}_{2}$, in an in vitro model of neuronally differentiated IMR32 neuroblastoma cells. Hydrogen peroxide was used as an inducer for oxidative stress. Cell viability was determined using MTT assay, apoptosis studies were carried out using Annexin V-FITC and Caspase 3 assays, mitochondrial membrane potential was examined using $\mathrm{JC} 1$ staining. The oxidative stress induced by $\mathrm{H}_{2} \mathrm{O}_{2}$ was determined by quantifying the intracellular reactive oxygen species production using DCF-DA staining. Mitogen activated protein kinase signaling pathway of the neuroprotective effect of PTE was also elucidated since oxidative stress activates this pathway signaling.

Results: Peltophorum pterocarpum leaf extract did not exhibit any cytotoxicity to differentiated IMR32 cells at the tested concentration of $7.8 \mu \mathrm{g} / \mathrm{ml}$ till $250 \mu \mathrm{g} / \mathrm{ml}$. Pre-treatment of differentiated IMR32 with Peltophorum pterocarpum leaf extract prior to exposure to $300 \mu \mathrm{M}$ hydrogen peroxide significantly ameliorated neuronal cell death and apoptosis in a dosedependent manner. Hydrogen peroxide induced oxidative stress caused the reduction of mitochondrial membrane potential in differentiated IMR32 cells. Peltophorum pterocarpum leaf extract conferred neuroprotection to differentiated IMR32 by increasing the mitochondrial membrane potential in a dose-dependent manner which was significantly higher at $125 \mu \mathrm{g} / \mathrm{ml}$ and $250 \mu \mathrm{g} / \mathrm{ml}$. PTE pre-treatment attenuated the increase of intracellular reactive oxygen species induced by hydrogen peroxide in a dose-dependent manner up till concentration of $125 \mu \mathrm{g} / \mathrm{ml}$. Western blot analysis on mitogen activated protein kinases (MAPKs) revealed that neuroprotection of Peltophorum pterocarpum leaf extract against hydrogen peroxide induced cytotoxicity was achieved by complete inhibition of the activation of phosphop-38 phosphorylation and attenuation of phospho-ERK1/2.
\end{abstract}

Conclusion: This study thus suggests that Peltophorum pterocarpum leaf extract has neuroprotective activity against oxidative-stress induced neuronal cell death.

Keywords: Antioxidant, Neuroprotective, Apoptosis, Oxidative stress, Reactive oxygen Species, Peltophorum pterocarpum

\footnotetext{
*Correspondence: thean@sirim.my; malarthean@gmail.com

'SIRIM Bhd, Industrial Biotechnology Research Centre (IBRC), No 1, Persiaran

Dato Menteri Seksyen 2, 40700 Shah Alam, Selangor, Malaysia

Full list of author information is available at the end of the article
} 


\section{Background}

Oxidative stress due to the over production of reactive oxygen species (ROS) during normal aerobic respiration in the neurons play an important role in the pathophysiology of many neurodegeneration diseases. Alzheimer's disease (AD), Parkinson's disease (PD), Amyotropic Lateral Sclerosis (ALS), and Huntington's disease (HD) are irreparable and debilitating neurodegenerative diseases that causes gradual damage to the structure, function and finally death of neurons [1]. Neuronal cells are particularly sensitive to oxidative stress because they are deficient in their internal anti-oxidant defense mechanism against damage by free radicals or ROS [2]. Since neurons are post-mitotic cells, neuronal cell death is irreversible. Thus, in order to prevent neuronal damage, anti-oxidant based natural products are much sought after for use as a preventive measure to combat oxidative stress induced cell death in neurons. There have also been a continuous effort to use natural based anti-oxidant compounds as neuroprotective adjunct in the prevention of neuronal cell death. Natural compounds such as curcumin [3, 4], huperzine A [5] and a standardized extract from Gingko biloba leaf (EGb761) [6] are some of the plant based compounds that have neuroprotective effect.

Peltophorum pterocarpum is a plant from the family of Leguminosae and a tropical tree found in South Eastern Asia. The leaves of Peltophorum pterocarpum have been reported to be hepatoprotective against paracetamol induced liver toxicity in albino Wistar rats mainly due to its anti-oxidant effect [7]. The methanolic extract of the bark of this plant was found to be neuroprotective against scopolamine induced memory loss in rats [8]. However, studies on the neuroprotective effect of the leaves have not yet been done. In this study, the PTE extract was explored for its in vitro neuroprotective properties against $\mathrm{H}_{2} \mathrm{O}_{2}$ induced cell death and oxidative stress on the differentiated IMR32 neuroblastoma cells (dIMR32).

\section{Methods}

\section{Plant material and extraction}

Fresh leaves of the Peltophorum pterocarpum were obtained from Block 19 of SIRIM Bhd, Shah Alam, Malaysia. The plant was authenticated by an herbalist from the Forest Research Institute of Malaysia (FRIM), Kepong. The leaves of the plant were washed with distilled water and dried in an oven at $40{ }^{\circ} \mathrm{C}$. The dried leaves were then powderized and extraction was carried out at room temperature for $24 \mathrm{~h}$ in an orbital shaker (at $200 \mathrm{rpm}$ ) using absolute ethanol (analytical grade, Merck) at concentration of 1:20 $(w / v)$ where $10 \mathrm{~g}$ of the leaves were extracted in $200 \mathrm{ml}$ of ethanol. After $24 \mathrm{~h}$ the suspension was filtered using a 114 Whatman filter paper and filtrate collected. The solvent filtrate was concentrated using a rotary evaporator.

\section{HPLC profiling of PTE Extract}

The HPLC profiling of ethanolic extract of Peltophorum pterocarpum leaves (PTE) was carried using Shimadzu HPLC instrument with UV visible PDA detector at $254 \mathrm{~nm}$. Chromatographic separation was accomplished by injecting the sample onto a Novapak C18 column $(250 \times 4.6 \mathrm{~mm}, 5-\mu \mathrm{m})$. The mobile phase consisted of solvent A: $0.1 \%$ formic acid in water and solvent B: $0.1 \%$ formic acid in acetonitrile; gradient starting from $10 \% \mathrm{~B}$ and $90 \% \mathrm{~A}$ for $14 \mathrm{mins}, 100 \% \mathrm{~B}$ and $0 \% \mathrm{~A}$ for $11 \mathrm{~min}, 10 \%$ $\mathrm{B}$ and $90 \% \mathrm{~A}$ for another $5 \mathrm{~min}$; then re-equilibrating prior to the next injection. The detection wavelength was $254 \mathrm{~nm}$ with a flow rate of $0.8 \mathrm{ml} / \mathrm{min}$ and an injection volume of $10 \mu \mathrm{l}$ was used.

\section{IMR32 cell culture and differentiation}

IMR32 (ATCC ${ }^{\oplus}$ CCL-127 ${ }^{\mathrm{TM}}$ ) neuroblastoma cell line, was purchased from ATCC. IMR32 cells were routinely maintained in complete Eagle's Minimum Essential Medium (EMEM, GIBCO) supplemented with $1 \mathrm{mM}$ sodium pyruvate, $1 \mathrm{mM}$ non-essential amino acids (NEAA, GIBCO), $10 \%$ fetal bovine growth serum (FBS, HyClone) and $1 \mathrm{X}$ antibiotic/antimycotic (HyClone) containing 10,000 units of penicillin, $10,000 \mu \mathrm{g}$ of streptomycin, and $25 \mu \mathrm{g}$ of Amphotericin B per milliliter. The cells were maintained in humidified $5 \% \mathrm{CO}_{2}$ incubator and passaged according to the recommended dilutions and confluency by ATCC. Differentiation of the IMR32 cells were carried out using RPMI medium (Gibco) supplemented with $1 \mathrm{mM}$ sodium pyruvate, $1 \mathrm{mM}$ non-essential amino acids (NEAA, GIBCO), 2\% FBS, Penicillin/Streptomycin and Amphoterin. Differentiation to neuronal phenotype was induced using $2.5 \mu \mathrm{M} 5 \mathrm{Brdu}$ (Sigma Aldrich) for 15 days with frequent change of medium every $48 \mathrm{~h}$. All subsequent cell culture analysis was done ut with the 15 days differentiated IMR32 (dIMR32) cells.

\section{Immunocytochemistry (ICC) to confirm neuronal phenotype in differentiated IMR32}

The neuronally differentiated IMR32 cells (dIMR32) were fixed in $4 \%$ paraformaldehyde at room temperature for $30 \mathrm{~min}$. After PFA fixing and washing with $1 \mathrm{xPBS}$, the neurons were permeabilized in permeabilization solution (1\% Triton-X in $1 \times$ PBS) at room temperature for $15 \mathrm{~min}$ and washed again in PBS. They were then blocked in blocking solution (0.3\% BSA, $1 \%$ goat serum, $0.1 \%$ Tween 20) at room temperature for $30 \mathrm{~min}$. After that, the cells of each well were incubated separately with the primary antibodies of class III beta tubulin (marker for postmitotic neurons), and choline acetyltransferase / ChAT (marker for cholinergic neurons) both diluted in blocking 
buffer at dilution (1:200; Abcam) and incubated overnight at $4{ }^{\circ} \mathrm{C}$. The next day, the cells were rinsed 3 times with $1 \times$ PBS and incubated with secondary antibodies, Alexa Fluor 488 goat anti-rabbit IgG (1:200; Abcam) for green fluorescence and Alexa Fluor 594 goat anti-rabbit IgG (1:200; Abcam) for red fluorescence, at room temperature in the dark for $2 \mathrm{~h}$. Nuclei were counterstained with $1 \mu \mathrm{g} /$ $\mu \mathrm{l}$ propidium iodide (PI) or DAPI $(5 \mu \mathrm{g} / \mathrm{ml}$, Molecular Probes) for $10 \mathrm{~min}$ and washed 3 times with $1 \times$ PBS. The cells were then viewed under Olympus IX51 inverted fluorescence microscope.

\section{Treatment of the differentiated IMR32 neurons (dIMR32) and MTT assay}

Cells were seeded at $5 \times 10^{4}$ cells $/ \mathrm{ml}$ in 24 well plates (Corning ${ }^{\circ}$ CellBIND $^{\circ}$ Surface cell culture flasks) for better attachment of cells and the cells grown to $70 \%$ confluence in complete EMEM for $48 \mathrm{~h}$. After $48 \mathrm{~h}$, the IMR32 cells were differentiated with $2.5 \mu \mathrm{M}$ for 15 days. On the 15th day, the differentiated cells were treated with serially diluted concentrations of PTE, starting from $250 \mu \mathrm{g} / \mathrm{ml}$ to $8 \mu \mathrm{g} / \mathrm{ml}$ for $24 \mathrm{~h}$ to determine the viability of differentiated (dIMR32). To study the neuroprotective effect of PTE against $\mathrm{H}_{2} \mathrm{O}_{2}$ cytotoxicity, the dIMR32 cells were pretreated for $24 \mathrm{~h}$ with the above concentrations of PTE, and then treated with the $300 \mu \mathrm{M}$ of $\mathrm{H}_{2} \mathrm{O}_{2}$ for $24 \mathrm{~h}$. All the treatments were done in RPMI medium without serum and sodium pyruvate. Sodium pyruvate was omitted from the medium because it is neuroprotective to dIMR32 cells and will interfere with the viability assay of the extracts. MTT assay to test the viability of the dIMR32 after treatment was carried out by adding $0.25 \mathrm{mg} / \mathrm{ml} \mathrm{MTT}$ to the cells for $3 \mathrm{~h}$. The medium was removed and the formazan formed was dissolved in DMSO and the absorbance was measured using a multiplate reader at $570 \mathrm{~nm}$ wavelength (Tecan, Austria). All experiments were done in triplicates. Results were expressed as percentage of the untreated cells.

$$
\text { Cell Viability }(\%)=\frac{\mathrm{OD}_{570 \mathrm{~nm}} \text { treatment }}{\mathrm{OD}_{570 \mathrm{~nm}} \text { untreated }} \times 100 \%
$$

\section{Apoptosis assay using annexin V FITC/ propidium iodide assay kit}

Apoptosis assay was conducted using Annexin V FITC Assay kit from Cayman Chemical, USA according to the manufacturer's protocol. Briefly after the required treatment, the dIMR32 cells were collected from each well and centrifuged at $1200 \mathrm{rpm}$ for $5 \mathrm{~min}$. The pellet was then re-suspended in $200 \mu \mathrm{l}$ binding buffer and then centrifuged again at $1200 \mathrm{rpm}$ for $5 \mathrm{~min}$ and the supernatant removed. The pellet is re-suspended in $50 \mu \mathrm{l}$ of the Annexin V FITC/PI staining solution and kept in dark for $10 \mathrm{~min}$. The cells were centrifuged again, supernatant discarded and the pellet was re-suspended in $150 \mu \mathrm{l}$ of $1 \times$ binding buffer and immediately analyzed using FACS Calibur Flowcytometer and Cell Quest Pro software (BD Biosciences, USA).

\section{Caspase 3 activity using fluorescence assay}

Caspases belong to the aspartic specific cysteinyl protease family and caspase 3 is an effector caspase and its activity is involved in both external and internal apoptosis. Caspase 3 assay is carried out using Cayman Chemical Fluorescence based assay kit. This kit utilizes a specific caspase 3 substrate N-Ac-DEVD-N'-MC-R110 which upon cleavage by active caspase 3 , generates a highly fluorescent product that is measured at excitation 485 and emission 535. Briefly, after treatment cells were harvested, washed in $200 \mu \mathrm{l}$ caspase 3 assay buffer, centrifuged at $1000 \mathrm{rpm}$ for $5 \mathrm{~min}$ and the supernatant was discarded. The cell pellets were then lysed in ice cold $1 \mathrm{X}$ Cell Lysis Buffer (10 mM Tris- $\mathrm{HCl}$ at $\mathrm{pH} 7.5,10 \mathrm{mM} \mathrm{NaH} \mathrm{PO}_{4} / \mathrm{NaHPO}_{4}$, $130 \mathrm{mM} \mathrm{NaCl}, 1 \%$ Triton X-100, $10 \mathrm{mM}$ sodium pyrophosphate) for $30 \mathrm{~min}$ with occasional vortexing. After centrifugation at $12,000 \mathrm{rpm}, 4{ }^{\circ} \mathrm{C}$ for $5 \mathrm{~min}, 90 \mu \mathrm{l}$ cell lysate was added to $10 \mu \mathrm{l}$ of caspase assay buffer and $100 \mu \mathrm{l}$ of caspase substrate solution. Caspase 3 substrate solution contains $100 \mu \mathrm{l}$ of caspase 3 substrate, $400 \mu \mathrm{l}$ dithiothreitol (DTT) and $9.5 \mathrm{ml}$ Caspase 3 assay buffer. The mixture was incubated at $37{ }^{\circ} \mathrm{C}$ for $30 \mathrm{~min}$ and fluorescence was read at an excitation wavelength of $485 \mathrm{~nm}$ and an emission wavelength of $535 \mathrm{~nm}$ using fluorescence plate reader (Tecan). Caspase 3 activity expressed in relative fluorescence unit (RFU) was normalized against protein concentration of the cell lysates which was determined using Bradford Assay. The results are expressed as relative fluorescence unit per microgram of protein (RFU/ $\mu$ g protein).

\section{Mitochondrial membrane potential $(\Delta \Psi \mathrm{m})$ assay using JC-1 kit}

The changes in Mitochondrial Membrane Potential (MMP or $\Delta \Psi \mathrm{m}$ ) were measured using JC-1 Mitochondrial Membrane Potential Assay Kit (Cayman Chemical. USA) as described in the manufacturer's protocol. After the required treatment, the cells were washed with the provided assay buffer and centrifuged at $1000 \mathrm{rpm}$ for $5 \mathrm{~min}$ and the supernatant was discarded. JC1 staining solution was prepared by diluting the stock in culture medium at 1:10 dilution ratio. The cell pellet was resuspended in $100 \mu \mathrm{l}$ of the JC1 staining solution and incubated in the dark at $37{ }^{\circ} \mathrm{C}$ for $30 \mathrm{~min}$. The cells were then centrifuged at $1200 \mathrm{rpm}$ for $5 \mathrm{~min}$ and supernatant removed. The pellet was then re-suspended in the $100 \mu \mathrm{l}$ assay buffer. The cells were then analyzed using black well plate and fluorescence plate reader at excitation $485 \mathrm{~nm}$ and emission $535 \mathrm{~nm}$ for green apoptotic cells 
and at emission $590 \mathrm{~nm}$ for red healthy cells using TECAN fluorescence plate reader. The ratio between healthy/apoptotic fluorescence readings was calculated. The ratio of the reading at $595 \mathrm{~nm}$ to the reading at $535 \mathrm{~nm}$ was considered as the relative $\Delta \Psi \mathrm{m}$ value.

\section{Intracellular ROS detection using DCFH-DA assay}

The degree of ROS generation in dIMR32 cells were measured using fluorescence assay with 2',7'-dichlorodihydrofluorescein diacetate (H2DCFDA, Sigma). Briefly, after treatment the cells were scraped and washed in PBS and the pellet re-suspended in $200 \mu \mathrm{l}$ of PBS loaded with $10 \mu \mathrm{M} \mathrm{H} 2$ DCFH-DA at $37^{\circ} \mathrm{C}$ for $30 \mathrm{~min}$ and then the cells were washed twice with PBS and centrifuged at $1000 \mathrm{rpm}$ for $5 \mathrm{~min}$. Finally, the pellet was re-suspended in $200 \mu \mathrm{l} \mathrm{PBS}$ and the fluorescence's intensity of DCF was measured with BD Biosciences Accuri C6 flow cytometer.

\section{Western blot analysis}

Briefly, after treatment as above, dIMR32 cells were harvested, cells were washed with PBS, centrifuged at $1000 \mathrm{rpm}$ for $10 \mathrm{~min}$, the supernatant was discarded and $200 \mu \mathrm{l}$ of iced-cold 1xRIPA buffer was added to the cell pellet in order to lyse the cells for protein extraction. The cells in the 1× RIPA buffer were placed on ice for $30 \mathrm{~min}$ with occasional vortexing. The samples were centrifuged at $12000 \mathrm{rpm}$ at $4{ }^{\circ} \mathrm{C}$ for $15 \mathrm{~min}$. The soluble proteins that were in the supernatant were transferred to a new $1.5 \mathrm{ml}$ centrifuge tubes. The protein concentration was quantified using the commercial Bradford Assay. The cell lysates samples were stored at $-80{ }^{\circ} \mathrm{C}$ for further use. Proteins were separated on a $12 \%$ SDS-polyacrylamide gel, and then transferred onto a polyvinylidene difluoride transfer membrane blots (Amersham Hybond P). The blots were blocked with $5 \%$ BSA in TBST buffer ( $25 \mathrm{mM}$ Tris- $\mathrm{HCl}, 140 \mathrm{mM}$ $\mathrm{NaCl}, 2 \mathrm{mM} \mathrm{KCl}, 0.05 \%(v / \mathrm{v})$ Tween 20) for $1 \mathrm{~h}$ at room temperature. The blots were then washed $3 \times$ for $10 \mathrm{~min}$ each time, with TBS-T. The blots were subsequently incubated with the primary antibody (Cell Signaling) overnight at $4{ }^{\circ} \mathrm{C}$ diluted in blocking buffer (each antibody at a dilution of 1:1000; phospho-JNK (Thr183/Tyr185), JNK, phospho-p38 (Thr180/Tyr182), p38, phospho-ERK 1/2 (Thr202/Tyr204) at 1:2000 and ERK1/2 (1:1000)). Beta Actin (Cell Signaling) was used as loading control with dilution (1:1000). After overnight incubation, the blots were then washed $3 \times$ (each $10 \mathrm{~min}$ ) with TBS-T and incubated at room temperature for $1 \mathrm{~h}$ with horseradish peroxidase conjugated anti-rabbit IgG secondary antibody (1:5000) diluted in TBS-T. The blots were washed again $3 \times$ each 10 min with TBS-T and developed using Amersham ECL Prime Western Blotting Detection Reagent at ratio of 1:1 (GE Healthcare Life Sciences). Protein bands were quantified by densitometric analysis using Image J software 1.46 (National Institute of Health, USA).

\section{Statistical analysis}

Results were expressed as the mean \pm SEM performed in triplicates. Graphs were plotted and data were analyzed by one-way analysis of variance ANOVA (Dunnett's test) using GraphPad Prism 6.0 software. The differences between the means of treated and untreated groups were considered significant at $p<0.05$.

\section{Results \\ HPLC profiling of the ethanolic extract of Peltophorum pterocarpum leaf (PTE)}

The results in Fig. 1 show the HPLC profile of PTE and it was found that the major bioactive peak is at the retention time $8.52 \mathrm{~min}$. As reported earlier the major compounds that are present in the leaves are the derivatives of quercetin among which are the (Fig. 1b) quercetin-3-O- $\beta$-D-galactoside [9] and Quercetin-3-O- $\beta$-D-glucuronide (Fig. 1c) (identified by our group in an unpublished earlier research).

\section{Immunocytochemistry (ICC) of differentiated IMR32 neurons}

Human neuroblastoma IMR32 cells were differentiated into neuronal-like cells by using 5 -Bromo-2'-deoxyuridine (5Brdu). Undifferentiated IMR32 cells consists of two types of cells which are the $\mathrm{N}$ type cells consisting of small round neuroblast cells with poor cell adherence to the surface (green arrows in Fig. 2a) and large adherent fibroblast cells (red arrows in Fig. 2a). When differentiated with $2.5 \mu \mathrm{M}$ $5 \mathrm{Brdu}$ in a low serum (2\%) medium, the cells stops proliferating and forms extensive network of neurites (red arrows in Fig. 2b) together with connected clumps of cells (green arrow in Fig. 2b). This differentiated IMR32 (dIMR32) cells express post mitotic neuronal marker of class III $\beta$ - tubulin III (Fig. 2c) and also express the ChAT (Choline Acetyltransferase) cholinergic neuronal cell marker (Fig. 2d).

\section{In vitro neuroprotective effect of ethanolic extract of Peltophorum pterocarpum leaf (PTE)}

Initial experiments were conducted to determine whether PTE extract was toxic to differentiated IMR32 (dIMR32). Figure 3a shows that treatment of dIMR32 with various concentration of PTE from $(8 \mu \mathrm{g} / \mathrm{ml}$ till $250 \mu \mathrm{g} / \mathrm{ml})$ did not show any cytotoxicity in the dIMR32 cells where its viability ranges from $(84,92,92,94,98$ and $95 \%)$ respectively. Consequently, the neuroprotective effect of PTE against $\mathrm{H}_{2} \mathrm{O}_{2}$ induced neurotoxicity were investigated. Differentiated IMR32 cells (dIMR32) were pretreated with various concentrations of PTE for $24 \mathrm{~h}$ followed by treatment with $300 \mu \mathrm{M} \mathrm{H}_{2} \mathrm{O}_{2}$ for $24 \mathrm{~h}$. As shown as in Fig. 3c, $\mathrm{H}_{2} \mathrm{O}_{2}$ induced loss of cell viability (64\%) was significantly attenuated by PTE pretreatment in a dose dependent manner with cell viability of $82,94,116,139,124$ and $103 \%$ at PTE concentrations of $8 \mu \mathrm{g} / \mathrm{ml}, 16 \mu \mathrm{g} / \mathrm{ml}, 31 \mu \mathrm{g} / \mathrm{ml}$, $63 \mu \mathrm{g} / \mathrm{ml}, 125 \mu \mathrm{g} / \mathrm{ml}$ and $250 \mu \mathrm{g} / \mathrm{ml}$ respectively. 


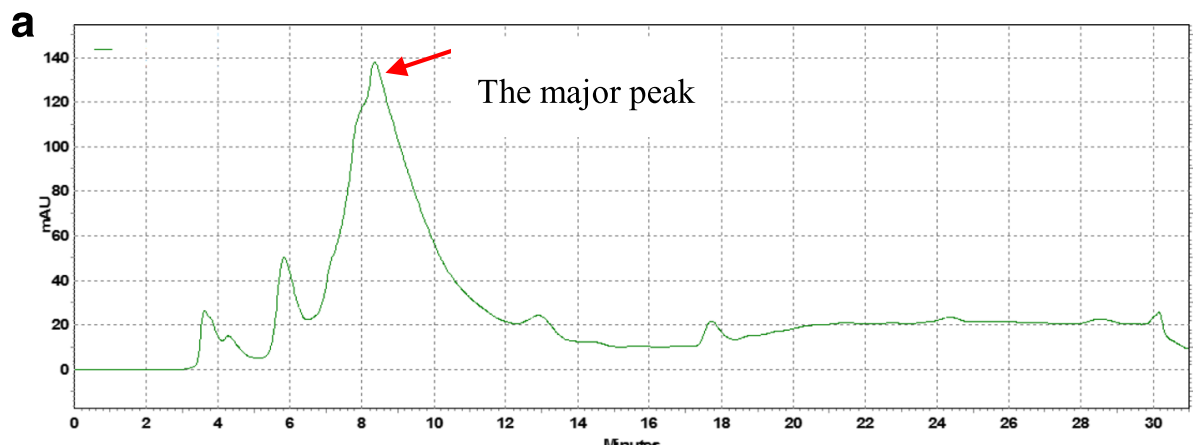

b

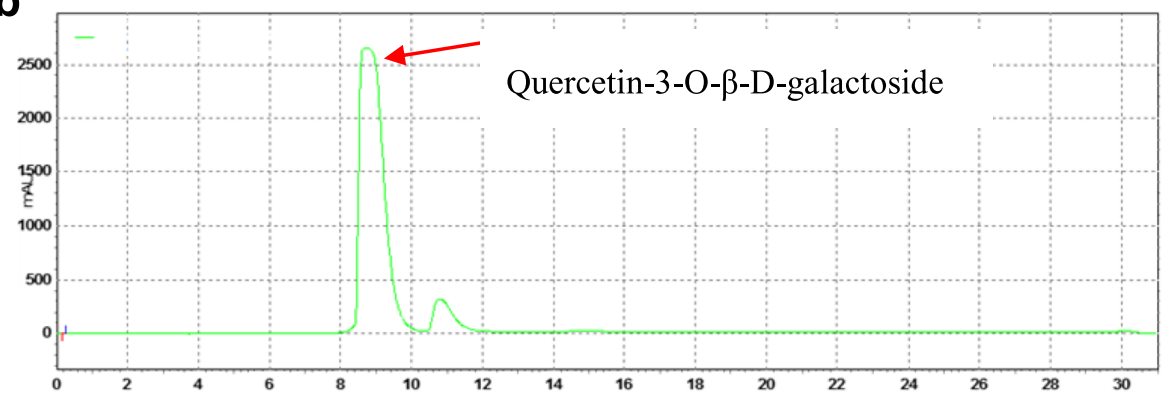

C

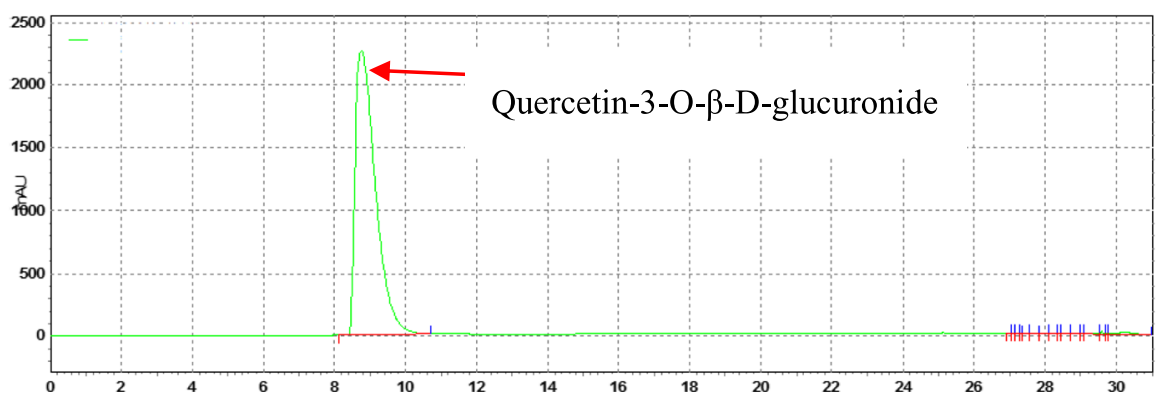

Fig. 1 a HPLC Profile of ethanolic extract of Peltophorum pterocarpum leaf (PTE) with detection at $254 \mathrm{~nm}$ using PDA detector. The major bioactive peak at retention time (RT) of 8.514 min that contains mainly quercetin derivatives namely b Quercetin-3-O- $\beta$-D-galactoside (hyperoside) and c Quercetin-3-O- $\beta$-Dglucuronide (Miquelianin)

\section{Effect of PTE against $\mathrm{H}_{2} \mathrm{O}_{2}$ induced apoptosis}

Apoptosis study was conducted using the Annexin $\mathrm{V}$ FITC/PI assay where Annexin binds to the intracellular phosphatidylserine (PS) in a calcium-dependent manner. In this study, PTE treatment (Fig. 4a) alone only exhibited minimal apoptosis in dIMR32 and the viability of the cells were above $74.3 \%$ on all tested concentrations of PTE which confirms the earlier MTT results that PTE is not cytotoxic to the dIMR32. The percentage of viable cells in the untreated group was $93.4 \%$, and from the group that was $24 \mathrm{~h}$ treated with PTE from concentration of $8 \mu \mathrm{g} / \mathrm{ml}, 16 \mu \mathrm{g} / \mathrm{ml}, 31 \mu \mathrm{g} / \mathrm{ml}, 63 \mu \mathrm{g} / \mathrm{ml}$, $125 \mu \mathrm{g} / \mathrm{ml}$ and $250 \mu \mathrm{g} / \mathrm{ml}$ were $90.8,93.4,86.8,90.6$, 79.9 and $74.3 \%$, respectively. Nevertheless, PTE treatment for $24 \mathrm{~h}$ increased the percentage of total apoptotic cells in a concentration dependent manner where in the untreated group total apoptotic cells (which include the early apoptotic, late apoptotic and necrotic cells) were
6.6\% and the PTE treated group from concentration of $8 \mu \mathrm{g} / \mathrm{ml}, 16 \mu \mathrm{g} / \mathrm{ml}, 31 \mu \mathrm{g} / \mathrm{ml}, 63 \mu \mathrm{g} / \mathrm{ml}, 125 \mu \mathrm{g} / \mathrm{ml}$ and $250 \mu \mathrm{g} / \mathrm{ml}$, the total apoptotic cells were 9.2, 6.6, 13.29.420.1 and $25.7 \%$ respectively.

The effect of PTE pre-treatment and then subsequent treatment with $300 \mu \mathrm{M} \mathrm{H}_{2} \mathrm{O}_{2}$ on apoptosis status of dIMR32 were evaluated (Fig. 4b). In the absence of $\mathrm{H}_{2} \mathrm{O}_{2}$ or in the untreated group, the majority (93.4\%) of the cells were viable and non-apoptotic (Annexin $\mathrm{V}^{-} \mathrm{PI}$ $\left.{ }^{-}\right)$. However, in the $\mathrm{H}_{2} \mathrm{O}_{2}$ treated group the viable cells were reduced to $51.9 \%$ cells and total apoptotic cells were at $48.1 \%$. The viable cells in the PTE pre-treated cells prior to $\mathrm{H}_{2} \mathrm{O}_{2}$ insult, increased in a concentration dependent manner $(8 \mu \mathrm{g} / \mathrm{ml}, 16 \mu \mathrm{g} / \mathrm{ml}, 31 \mu \mathrm{g} / \mathrm{ml}, 63 \mu \mathrm{g} /$ $\mathrm{ml}, 125 \mu \mathrm{g} / \mathrm{ml}$ and $250 \mu \mathrm{g} / \mathrm{ml}$ ) from 56.2, 62.7, 69.2, $79.8,50.6$ and $71.4 \%$. PTE pre-treatment prior to $300 \mu \mathrm{M} \mathrm{H}_{2} \mathrm{O}_{2}$ insult significantly reduced the percentage of total apoptosis cells in a concentration dependent 

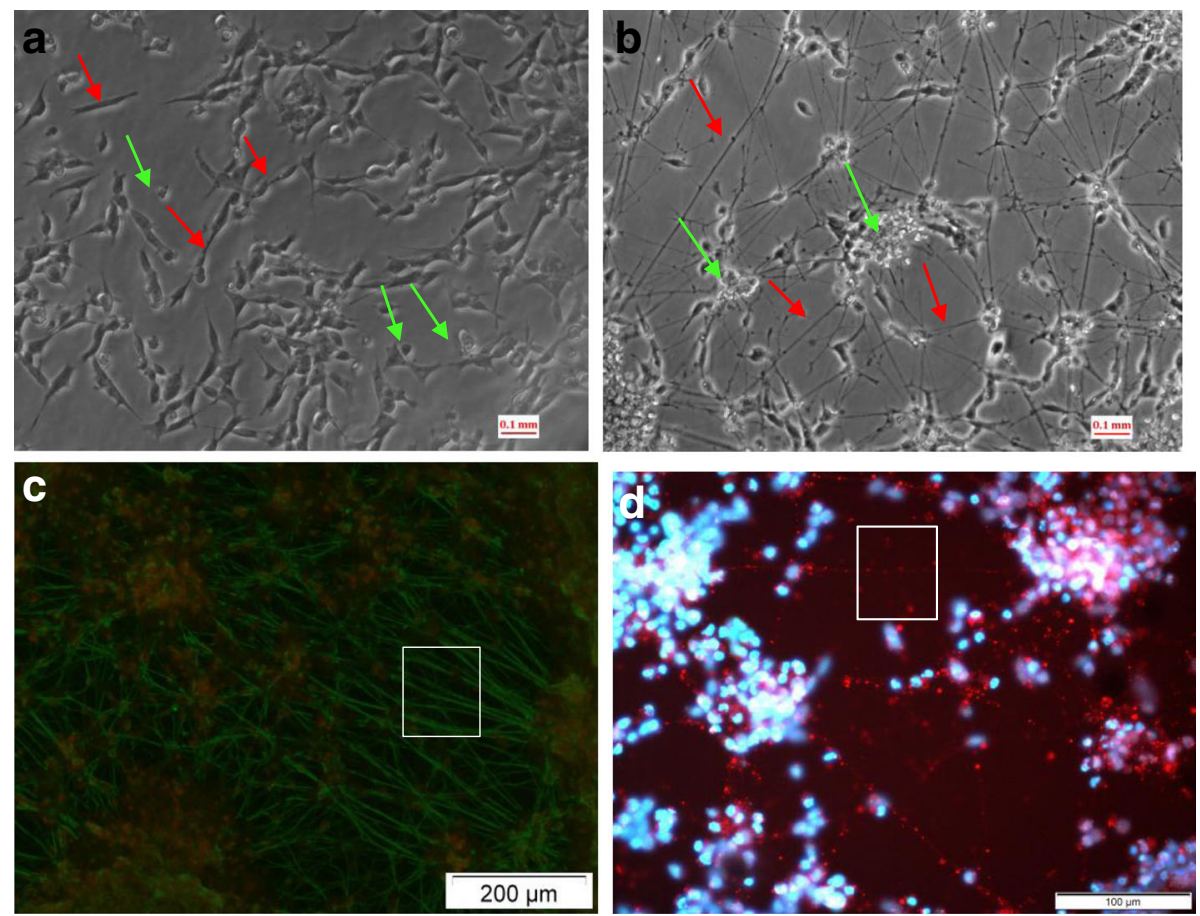

Fig. 2 Images of IMR32 cells. a Phase contrast image of undifferentiated human neuroblastoma IMR32 cells. Its shows proliferating cells. The red color arrows indicate fibroblast type cells and green. Color arrow indicate neuroblast type cells. b 2.5 MM Brdu differentiated human IMR32 cells (Div15 days). It shows neuron like properties including neuritic outgrowth and morphological changes. Red arrows shows the elongated neurites, green arrows connected clumps of cells. c ICC image of the expression of class III Beta-tubulin neuron marker in Div15 dIMR32 cells. Nuclei stained in Propidium iodide (PI red) and post mitotic neurons staining with class III $\beta$-tubulin (green). $\mathbf{d}$ Expression of ChAT (Choline Acetyltransferase) cholinergic neuron cell marker in dIMR32 cells. Nuclei stained with DAPI (blue) and cholinergic neurons stained with ChAT (red)

manner from $8 \mu \mathrm{g} / \mathrm{ml}, 16 \mu \mathrm{g} / \mathrm{ml}, 31 \mu \mathrm{g} / \mathrm{ml}, 63 \mu \mathrm{g} / \mathrm{ml}$ which were $43.8,31.2,30.8$ and $20.2 \%$ respectively as compared to the percentage total apoptotic cells of $48.1 \%$ in $300 \mu \mathrm{M} \mathrm{H}_{2} \mathrm{O}_{2}$ treated group (Fig. 4b). However, there was higher percentage of total apoptotic cells (40.5\%) at $125 \mu \mathrm{g} / \mathrm{ml}$ PTE pretreated group as compared to $28.6 \%$ at $250 \mu \mathrm{g} / \mathrm{ml}$ PTE pre-treated group.

\section{Neuroprotective effect of PTE against $\mathrm{H}_{2} \mathrm{O}_{2}$ cytotoxicity on caspase 3 activity}

Caspase 3 is the major executioner caspase that is involved both in mitochondrial mediated apoptosis and the extrinsic apoptosis. The effect of PTE pretreatment on the $\mathrm{H}_{2} \mathrm{O}_{2}$ induced caspase 3 activity in dIMR32 cells were evaluated. Figure 5 shows the Caspase 3 activity (in terms of RFU/ $\mathrm{g}$ g protein) after pretreatment with PTE for $24 \mathrm{~h}$ and then treatment with $\mathrm{H}_{2} \mathrm{O}_{2}$ for $24 \mathrm{~h}$. However, contrary to what was expected, $\mathrm{H}_{2} \mathrm{O}_{2}$ treatment (with caspase 3 activity of $420 \mathrm{RFU} / \mu \mathrm{g}$ protein) did not significantly increase caspase 3 activity as compared to untreated cells (with caspase 3 activity of $437 \mathrm{RFU} / \mu \mathrm{g}$ protein). It might be possible that $\mathrm{H}_{2} \mathrm{O}_{2}$ caused reversible inactivation of caspase 3 activity [10].

There was no significant decrease in the caspase 3 activity in the cells pre-treated with PTE from concentration of
$8 \mu \mathrm{g} / \mathrm{ml}, 16 \mu \mathrm{g} / \mathrm{ml}, 31 \mu \mathrm{g} / \mathrm{ml}, 63 \mu \mathrm{g} / \mathrm{ml}$ and $125 \mu \mathrm{g} / \mathrm{ml}$. The caspase 3 activity in these concentration were 487 , 465, 529, 582 and 594 RFU/ug protein. The caspase 3 activity was significantly high at $250 \mu \mathrm{g} / \mathrm{ml}$ pre-treated cells at $931.5 \mathrm{RFU} / \mu \mathrm{g}$ protein as opposed to $420 \mathrm{RFU} / \mu \mathrm{g}$ protein in $\mathrm{H}_{2} \mathrm{O}_{2}$ treated cells.

Effect of PTE pre-treatment on $\mathrm{H}_{2} \mathrm{O}_{2}$ induced reduction of Mitochondrial Membrane Potential (MMP) $\Delta \psi \mathrm{M}$

Mitochondria is the major organelle where oxidative stress happens and it is the major source of ROS production which is produced during mitochondrial electron transport. Mitochondrial dysfunction leads to the loss of mitochondrial trans-membrane potential (MMP) which changes the permeability of mitochondrial and thus release soluble proteins such as cytochrome $C$ or other apoptotic related proteins and activate caspase cascade [11]. Loss of MMP is an early sign of apoptosis. In this study, JC1 a cationic dye that accumulates in healthy or energized mitochondria was used. When mitochondria has low $\Delta \psi \mathrm{M}$ due to apoptosis, JC-1 is predominantly a monomer that yields green fluorescence with emission of $(530 \pm 15 \mathrm{~nm})$ and when it has high $\Delta \psi \mathrm{M}$ and healthy the dye enters the mitochondria and aggregates, thus yielding a red to orange colored 

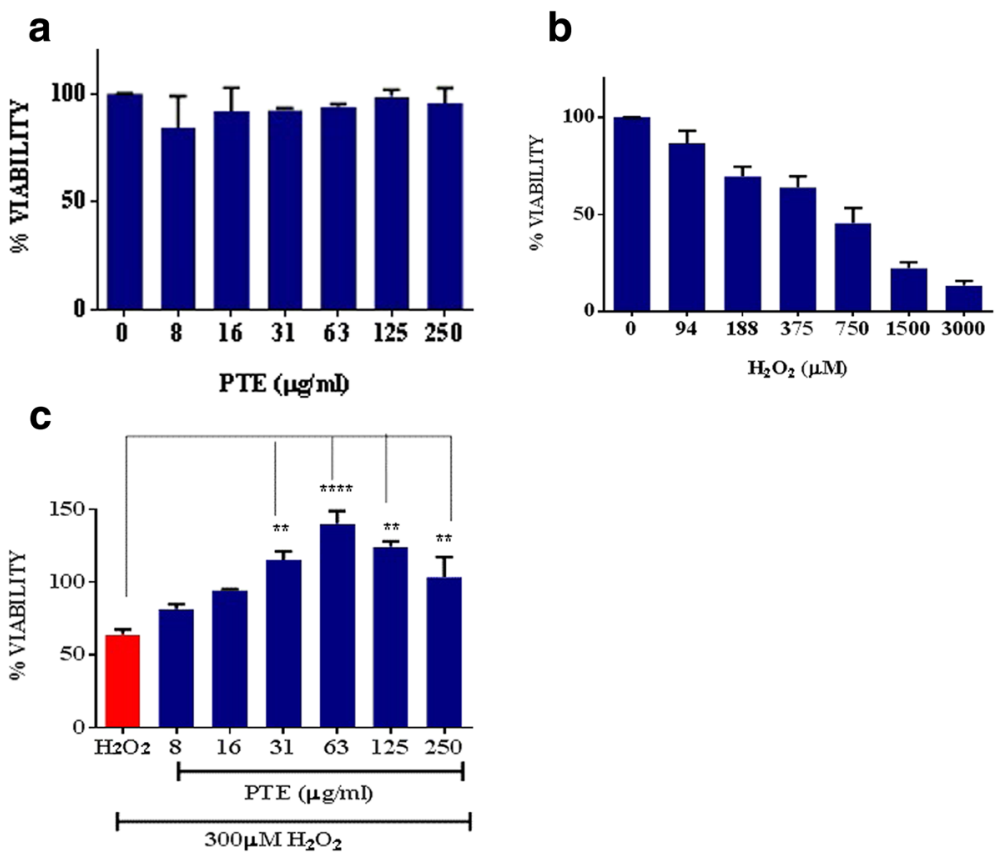

Fig. 3 a Effect of PTE on dIMR32 cells viability after exposure for $24 \mathrm{~h}$. No statistical difference were observed between doses. $\mathbf{b}$ Effect of $\mathrm{H}_{2} \mathrm{O}_{2}$ on dIMR32 cells viability after exposure for $24 \mathrm{~h}$. There is a dose-dependent reduction in viability of dIMR32 cells. c Neuroprotective effect of PTE pretreatment (24 h) against $\mathrm{H}_{2} \mathrm{O}_{2}$ induced cytotoxicity in dIMR32 cells. The data are expressed as mean $\pm \mathrm{SEM}, n=3$. Statistical significance was analyzed with one-way analysis of variance followed by Dunnett's multiple comparison post-hoc test. Differences with $p$ value less than 0.0001 and $p$ value less than 0.05 against $300 \mu \mathrm{M} \mathrm{H}_{2} \mathrm{O}_{2}$ treatment were considered statistically significant. ${ }^{* * *} p<0.0001$ and ${ }^{* *} p<0.05$

emission (590 $\pm 17.5 \mathrm{~nm})$. Therefore, depolarization happens when the aggregate (healthy cells) red fluorescent count decrease whereas hyperpolarization happens when the red fluorescent count increase. In this study, $\mathrm{H}_{2} \mathrm{O}_{2}$ induced cells have significantly lower $\Delta \psi \mathrm{M}$ based on the lower RFU ratio between red/green fluorescent (Fig. 6). However, pretreatment with PTE increased the $\Delta \psi_{\mathrm{M}}$ by the increase in ratio (in arbitrary units) of red/green fluorescent in a dose-dependent manner where it is significantly higher at 250 and $125 \mu \mathrm{g} / \mathrm{ml}(0.91$ and 0.82 , respectively) as opposed to 0.46 in $\mathrm{H}_{2} \mathrm{O}_{2}$ treated cells.
Effect of PTE pre-treatment on the intracellular ROS detection production

$\mathrm{H}_{2} \mathrm{O}_{2}$ induced cytotoxicity causes mitochondrial dysfunction and leads to the production of reactive oxidative species (ROS) which subsequently activates the apoptosis cascade. ROS generation in dIMR32 cells was determined using ROS-sensitive fluorescence indicator DCFH-DA. Figure 7 shows that exposure of dIMR32 to $300 \mu \mathrm{M}$ of $\mathrm{H}_{2} \mathrm{O}_{2}$ significantly increased the ROS production to $54 \%$ as compared to the untreated cells (38\%). The pre-treatment of PTE reduced the production ROS
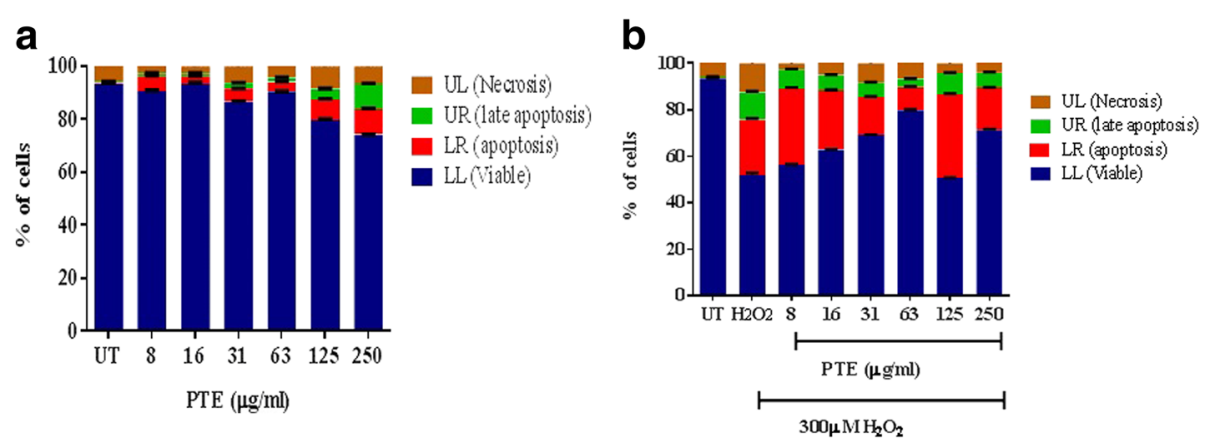

Fig. 4 a Effect of PTE treatment for $24 \mathrm{~h}$ on dIMR32 cells apoptosis. $\mathbf{b}$ Effect of PTE pre-treatment ( $24 \mathrm{~h}$ ) against $\mathrm{H}_{2} \mathrm{O}_{2}$ induced apoptosis in dIMR32 cells. The data are expressed as mean $\pm \mathrm{SEM}, n=3$. The label UT = untreated control cells. Statistical significance was analyzed with one way ANOVA followed by Dunnett's multiple comparison post-hoc test. There was significant differences with the number of apoptotic cells between $300 \mu \mathrm{M} \mathrm{H} \mathrm{H}_{2}$ treated cells and PTE pre-treated cells for all the tested concentration with $p<0.0001$ 


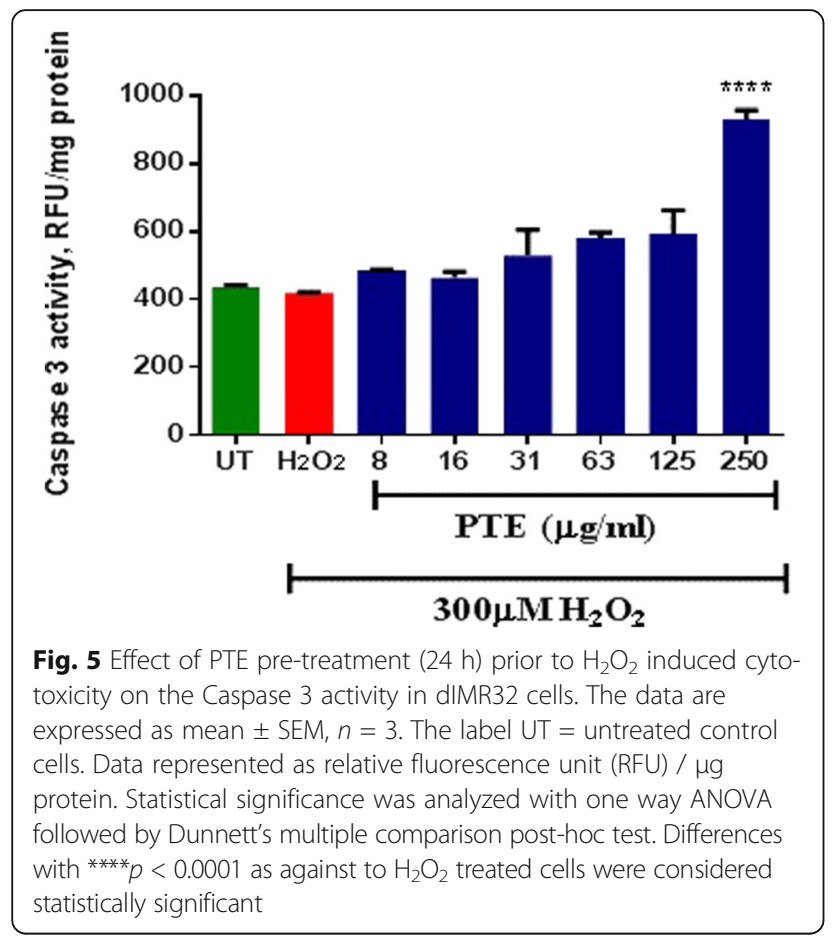

in a dose-dependent manner from concentration of $7.8 \mu \mathrm{g} / \mathrm{ml}$ to $125 \mu \mathrm{g} / \mathrm{ml}$ of PTE. However, pre-treatment with $250 \mu \mathrm{g} / \mathrm{ml}$ of PTE increased the ROS production to $68 \%$. This could be due to presence of certain compounds in the PTE that could have contributed to extra free radicals in cells on top of the oxidative stress induced by $\mathrm{H}_{2} \mathrm{O}_{2}$. This was also observed in Fig. 4b, where total apoptotic cells (28.6\%) were higher at $250 \mu \mathrm{g} / \mathrm{ml}$ PTE pre-treated cells even though the viable cells were at $71.4 \%$.

Effect of PTE pre-treatment on phosphorylation of MAPKs MAPKs play an important role in responding to various biological stimulus which includes oxidative stress in neuronal cells and thus regulate cell death or survival. Hence, western blot analysis of MAPKs protein was utilized to study the mechanism by which PTE pretreatment protects dIMR32 cells against neuronal cell death induced by $\mathrm{H}_{2} \mathrm{O}_{2}$. The p38 protein is generally activated in neuronal cells via phosphorylation during oxidative stress and other extracellular stimulus. In this study, high level of phospho-p38, phospho-ERK and phospho-JNK in untreated cells as compared to $2 \mathrm{~h}$ $\mathrm{H}_{2} \mathrm{O}_{2}$ treated cells were observed as in Fig. 8a-c. This may be the result of the IMR32 neuronal differentiation, as p38, ERK and JNK also regulate differentiation [12]. However, PTE pre-treatment completely inhibited the phosphorylation of p38 as compared to $2 \mathrm{~h} \mathrm{H}_{2} \mathrm{O}_{2}$ treated dIMR32 cells (Fig. 8d). PTE pre-treatment also significantly attenuated the phosphorylation of ERK1/2 as compared to $\mathrm{H}_{2} \mathrm{O}_{2}$ treated IMR32 cells at both the concentrations of PTE (Fig. 8e). This suggests that PTE provides protection to dIMR32 via inhibiting the p38 phosphorylation and decreasing the activation of the ERK1/2 signaling protein. PTE pre-treatment also exhibited a decreasing trend in phospho-JNK (Fig. 8f).

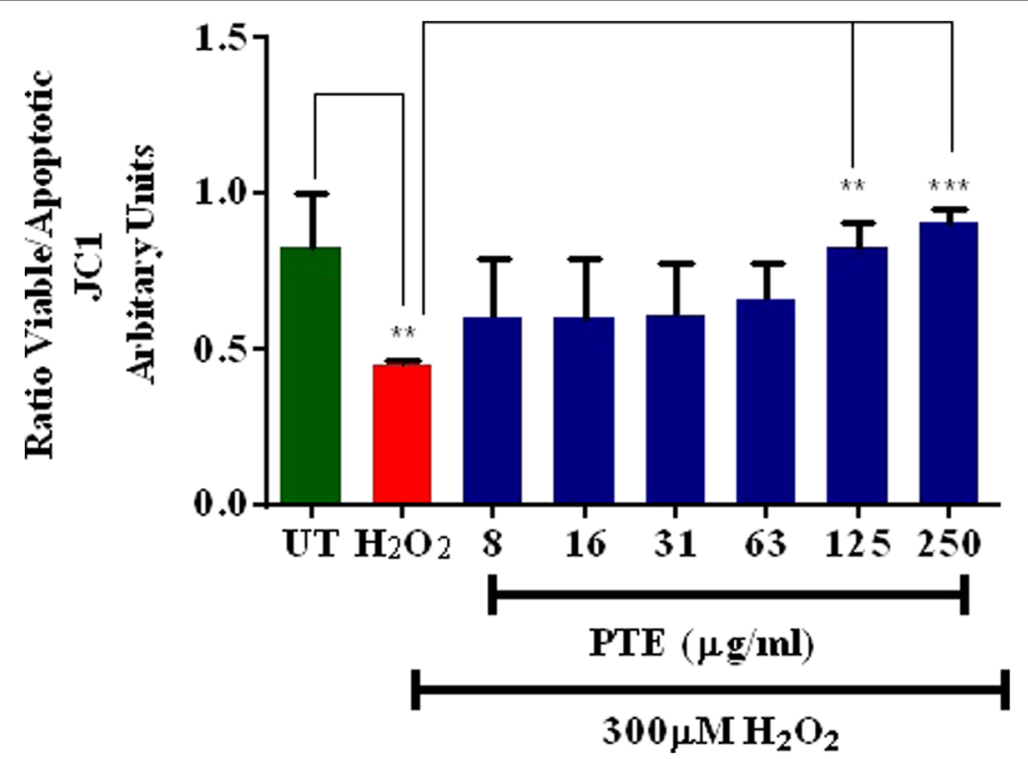

Fig. 6 Effect of PTE pre-treatment (24 h) on $\mathrm{H}_{2} \mathrm{O}_{2}$ induced decrease in Mitochondrial Membrane Potential (MMP) in dIMR32 cells. Data reported as Ratio between relative fluorescence unit (RFU) of viable cells / RFU of apoptotic cells. The ratio is an arbitrary unit. The label UT = untreated control cells. The higher ratio shows healthy cells and lower ratio shows apoptotic cells. The data are expressed as mean $\pm S E M, n=3$. Statistical significance was analyzed with one-way ANOVA followed by a Dunnett's multiple comparison post-hoc test. Differences with $p$ value less than 0.05 and less than 0.001 were considered statistically significant. ${ }^{* *} p<0.05$ and ${ }^{* *} p<0.001$ compared with $\mathrm{H}_{2} \mathrm{O}_{2}$ treated cells 


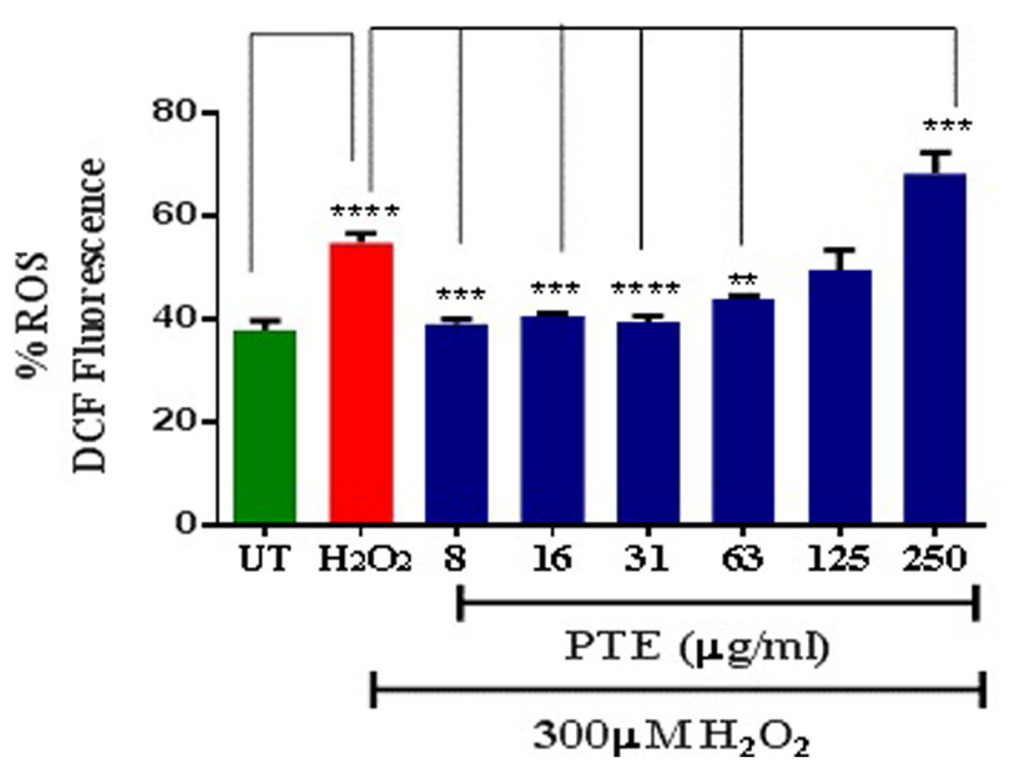

Fig. 7 Effect of PTE pretreatment ( $24 \mathrm{~h}$ ) on ROS production by $\mathrm{H}_{2} \mathrm{O}_{2}$ in dIMR32 cells. The data are expressed as mean $\pm \mathrm{SEM}, n=3$. The label UT = untreated control cells. Statistical significance was analyzed with one-way ANOVA followed by Dunnett's multiple comparison post-hoc test. Differences with $p$ value less than $p<0.0001, p<0.001$ and $p<0.05$ against $300 \mu \mathrm{M} \mathrm{H}_{2} \mathrm{O}_{2}$ treatment were considered statistically significant. ${ }^{* * * *} p<0.0001,{ }^{* * *} p<0.001$ and ${ }^{* *} p<0.05$

\section{Discussion}

This study used differentiated human neuroblastoma cell line IMR32 (dIMR32) as an in vitro model to study the neuroprotective effect of PTE extract against oxidative stress induced cytotoxicity (Fig. 2a and b). The results showed that IMR32 cells differentiated for 15 days (Div15) with $2.5 \mu \mathrm{M} 5 \mathrm{Brdu}$ induced formation of extensive network of neurites which expressed the postmitotic neuronal protein marker of class III $\beta$-tubulin and also the ChAT (choline acetyltransferase) cholinergic neuronal marker (Fig. 2c and d). Choline acetyltransferase is the enzyme that regulates the synthesis of neurotransmitter acetylcholine. It catalyzes the transfer of acetyl group from the acetyl-CoA to choline and produces acetylcholine. ChAT is produced in the body of neurons and is transported to the nerve terminal [13]. Among its other functions, acetylcholine is pivotal in the development and maintenance of memory and cognitive function in the brain [14]. Thus, this suggest that dIMR32 cells can serve an in vitro model to study neuroprotective effect of plant bioactives that affects the memory function in the brain.

Peltophorum pterocarpum leaves have been reported to have many anti-oxidant based bioactive compounds such as quercetin 3-O-galactoside, methyl derivatives of quercetin, naringenin, luteolin and various other antioxidant based compounds $[9,15]$. Thus, it was used in this study as a bioactive extract to determine its neuroprotective effect against $\mathrm{H}_{2} \mathrm{O}_{2}$ induced oxidative stress and cytotoxicity. Based on our HPLC profiling Fig. 1b and $\mathrm{c}$ we have found the presence of quercetin derivatives of Hyperoside and Miquelianin that can act as antioxidative neuroprotective agents against $\mathrm{H}_{2} \mathrm{O}_{2}$ induced cytotoxicity. The study identified that treatment with PTE extract alone did not exhibit cytotoxicity towards the dIMR32 cells and showed neuroprotection against $\mathrm{H}_{2} \mathrm{O}_{2}$ induced cytotoxicity (Fig. 3ac, bc \& c). $\mathrm{H}_{2} \mathrm{O}_{2}$ is widely used an as inducer of oxidative stress in many research involving the study of neuroprotection by phytochemicals as it has high membrane permeability and can induce cytotoxicity in the cells $[16,17]$.

We further studied the neuroprotective mechanism of PTE against $\mathrm{H}_{2} \mathrm{O}_{2}$ induced oxidative stress and cytotoxicity by exploring its effect on the apoptosis in the dIMR32 cells. Apoptosis mediated cell death causes the externalization of phosphatidylserine (PS) on the plasma membrane and thus causing an increase in Annexin $\mathrm{V}$ and propidium iodide (PI) stained cells in Flow cytometry analysis [18]. $\mathrm{H}_{2} \mathrm{O}_{2}$ treatment is known to cause cell death via apoptosis $[19,20]$ and our results showed that PTE pre-treatment substantially attenuated the $\mathrm{H}_{2} \mathrm{O}_{2}$ induced apoptosis in dIMR32 cells in a dose-dependent manner (from $8 \mu \mathrm{g} / \mathrm{ml}$ to $250 \mu \mathrm{g} / \mathrm{ml}$ ) except at the concentration of $125 \mu \mathrm{g} / \mathrm{ml}$ (Fig. 4a \& b). This discrepancy in our opinion could have been attributed to the stress that might have occurred during handling of cells while harvesting the cells for the assay. Nevertheless, the results suggest that pretreatment of dIMR32 cells with PTE exerts a neuroprotective effects onto the dIMR32 through inhibition of $\mathrm{H}_{2} \mathrm{O}_{2}$ induced apoptotic cell death. 


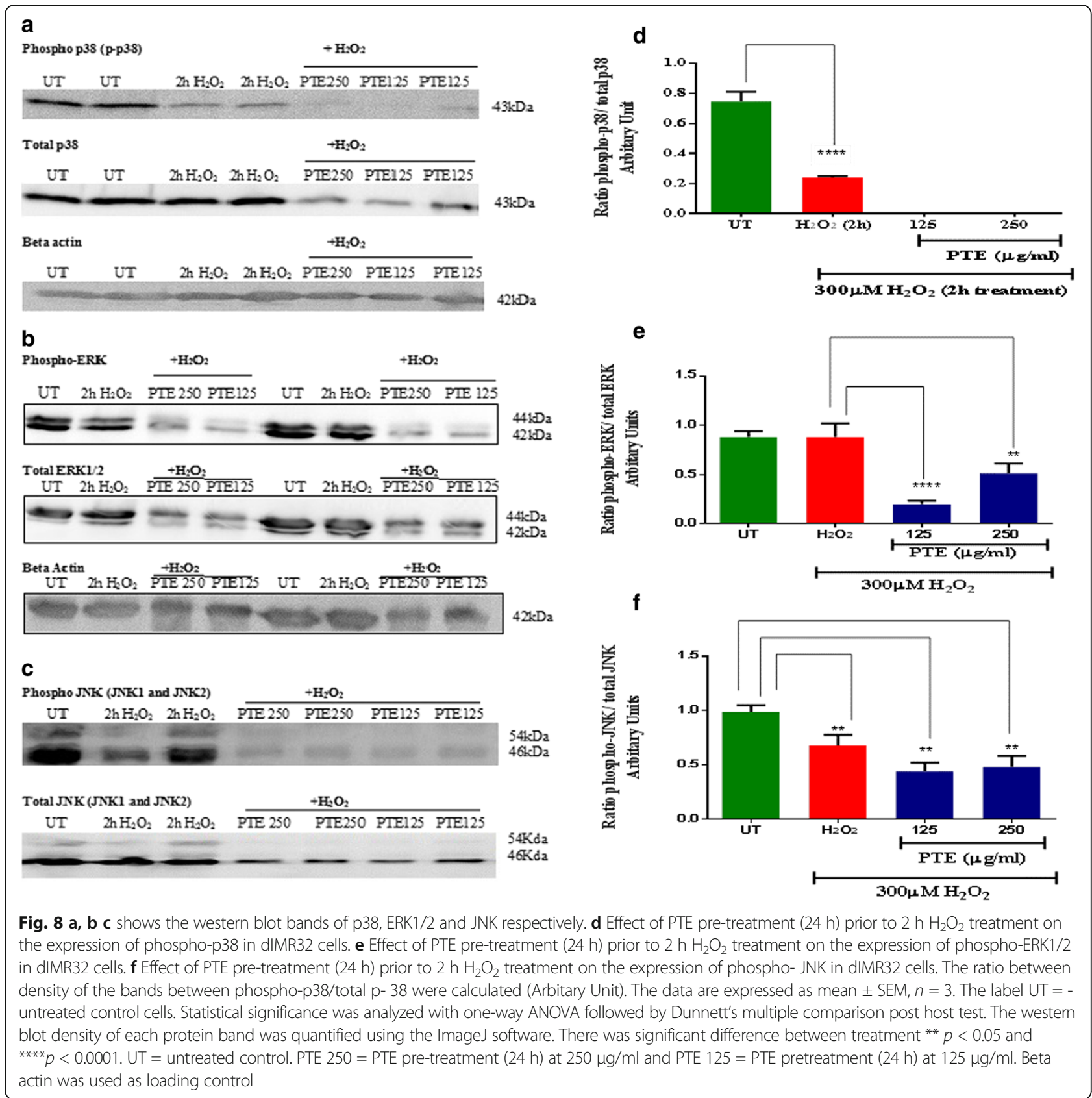

$\mathrm{H}_{2} \mathrm{O}_{2}$ induced apoptosis generally leads to the activation of the cysteine protease caspase cascade. Among them the caspase 3 activity is most commonly studied upon in neuronal cells [21]. Caspase 3 is the main effector caspase that is involved in both external and internal apoptosis pathway and it is the most abundant caspase in the brain [22]. Most research have shown that during $\mathrm{H}_{2} \mathrm{O}_{2}$ treatment of neuronal cells, the caspase 3 activity is increased and this leads to the apoptotic cell death of neurons. For example in SKNSH neuroblastoma cells, treatment with $150 \mu \mathrm{M} \mathrm{H}_{2} \mathrm{O}_{2}$ significantly increased the caspase 3 activity [23]. However, in our study, contrasting results were observed where treatment with $300 \mu \mathrm{M} \mathrm{H}_{2} \mathrm{O}_{2}$ did not increase the caspase 3 activity and PTE pre-treatment did not have any effect on the caspase 3 activity except at the highest concentration (Fig. 5). These results indicate that PTE pretreatment does not affect the caspase 3 activity in dIMR32 cells and the mechanism of neuroprotection might be caspase independent. The possible reason why $\mathrm{H}_{2} \mathrm{O}_{2}$ treated dIMR32 cells did not show increase in caspase 3 activity could be because $300 \mu \mathrm{M}$ of $\mathrm{H}_{2} \mathrm{O}_{2}$ might have caused necrosis to the cells. Necrotic cells do not express caspase 3 activity because caspases are sensitive 
to oxidative inactivation [24]. This kind of phenomena was observed in Jurkat-T-Lymphocytes where at low concentration of $\mathrm{H}_{2} \mathrm{O}_{2}(50 \mu \mathrm{M})$ the cells goes through apoptosis by activating caspase 3 activity starting at $3 \mathrm{~h}$ and peaking at $6 \mathrm{~h}$ [25]. However, higher concentrations of above $200 \mu \mathrm{M} \mathrm{H}_{2} \mathrm{O}_{2}$ decreased caspase 3 activity because cells were undergoing necrosis and high concentration of $\mathrm{H}_{2} \mathrm{O}_{2}$ also can directly inhibits cysteine-dependent caspase $[10,26]$.

Mitochondria plays an important role in $\mathrm{H}_{2} \mathrm{O}_{2}$ induced apoptosis and cell death. Mitochondrial dysfunction caused by $\mathrm{H}_{2} \mathrm{O}_{2}$ causes the collapse of the electrochemical gradient or mitochondrial membrane potential (referred to as $\Delta \Psi \mathrm{m}$ or MMP) across the mitochondrial membrane. This releases into the cytosol key apoptogenic proteins that triggers cell demise via apoptosis [27, 28]. Mitochondrial permeability transition pore (MPTP) is a voltage sensitive ion channel that resides in the inner mitochondrial membrane. This channel opens up under oxidative stress thus permitting the movement of large molecular weight solutes between the mitochondrial matrix and cytoplasm [27]. Thus, $\mathrm{H}_{2} \mathrm{O}_{2}$ induced oxidative stress in cells causes the inner membrane of mitochondria (which is normally impermeable) to become permeable, leading to a "large amplitude swelling" (permeability transition) and the loss of the mitochondrial membrane potential. The results in this study show that PTE pre-treatment attenuated the loss of MMP induced by $\mathrm{H}_{2} \mathrm{O}_{2}$ in a dose-dependent manner and the reduction was significant at the highest concentration of $125 \mu \mathrm{g} / \mathrm{ml}$ and $250 \mu \mathrm{g} / \mathrm{ml}$ of PTE (Fig. 6). The results suggest that PTE is neuroprotective against $\mathrm{H}_{2} \mathrm{O}_{2}$ induced oxidative stress and cytotoxicity in dIMR32 cells via the mitochondrial pathway by altering the mitochondrial membrane potential and thus reducing cascade of events that leads to apoptosis.

Oxidative stress induced by exogenous $\mathrm{H}_{2} \mathrm{O}_{2}$ not only causes apoptosis mediated cytotoxicity and mitochondrial dysfunction, it also leads to the generation of intracellular reactive oxygen species (ROS) in the cells. The ROS generated by the cells are determined by using the non-ionic and non-polar fluorescent dye 2,7-dichlorfluoresceindiacetate (DCFH-DA). The ROS that is produced during the oxidative stress converts the DCFH-DA into DCF which emits fluorescence that is directly proportional to the amount of ROS generated. Our studies show that PTE pre-treatment prior to $\mathrm{H}_{2} \mathrm{O}_{2}$ induced oxidative stress attenuated the production of ROS in dIMR32 cells in a dose-dependent manner (Fig. 7) except at the highest concentration of $250 \mu \mathrm{g} / \mathrm{ml}$ even though the cells did not show cytotoxicity at this concentration as reported earlier in Fig. 3a. However, based on the apoptosis results in Fig. $4 \mathrm{a}$, the percentage of apoptotic cells were $28.6 \%$ at this concentration and thus could have contributed to the higher ROS production in the PTE pre-treated cells. The higher ROS production at this concentration could also be due to the presence of certain polyphenols and antioxidants that is present in PTE which could have undergone redox recycling and thus produced more $\mathrm{H}_{2} \mathrm{O}_{2}$ which contribute to higher ROS [29-31]. Some compounds such as L-Dopa, dopamine, epigallocatechin, catechin, quercetin and epigallocatechin gallate can react with many cell culture medium and generate $\mathrm{H}_{2} \mathrm{O}_{2}[29$, 32-34]. In fact, the results correlate with the higher caspase 3 activity at $250 \mu \mathrm{g} / \mathrm{ml}$ PTE pre-treated cells as shown earlier in Fig. 5.

$\mathrm{H}_{2} \mathrm{O}_{2}$ induced oxidative stress in cells regulates many intracellular signaling pathway and among them are the MAPKs which consist of the extra cellular signal regulated kinase (ERK1/2), stress activated p38 and JNK. $\mathrm{H}_{2} \mathrm{O}_{2}$ normally stimulates the activation of MAPKs via phosphorylation and thus regulate the intracellular signaling pathway, which results either in cell survival or cell death [35]. However, in this work, $\mathrm{H}_{2} \mathrm{O}_{2}$ treated dIMR32 cells had lower level of phospho p-38, ERK1/2 and JNK (Fig. 8 d, e and f) as compared to untreated cells. This is because MAPKs are activated during neuronal differentiation process of cells [36, 37]. ERK1/2 or p44/42 is usually activated during cell growth, cell differentiation, cell survival, and motility. ERKs are highly expressed in post-mitotic neurons and in differentiated cells and involved in adaptive responses such as longterm potentiation in post mitotic neurons and in regulating synaptic plasticity of the hippocampus [38-40]. Thus, activation of the ERK1/2 can either lead to proliferation or differentiation of cells subjected to the strength and duration of the stimulation [41, 42]. On the other hand, p38 is phosphorylated during inflammation, cell cycle, cell death, development, cell differentiation, senescence, and tumorigenesis. JNK is also activated during many cellular events, such as growth control, transformation, and apoptosis [43-45].

Our results showed (Fig. 8d, e and f) that PTE pretreatment prior to inducing oxidative stress with $\mathrm{H}_{2} \mathrm{O}_{2}$, completely inhibited the activation or phosphorylation of p-38 as compared to the $\mathrm{H}_{2} \mathrm{O}_{2}$ treated cells. It also attenuated the phosphorylation of ERK1/2 and showed a decreasing trend of phospho-JNK, even though it was not statistically significant. The p-38 and JNK are stress activated MAPKs and they also regulate stress induced apoptosis [46]. On the contrary, ERK1/2 is a MAPKs that is generally activated for survival of cells. Nevertheless, it is also activated in some neuronal cells under $\mathrm{H}_{2} \mathrm{O}_{2}$ induced oxidative stress [47]. The effect of ERK1/ 2 activation on the pro-survival or pro-apoptotic roles in the cells depends on the kinetics, duration, stimulus and cell type [42, 48, 49].

Oxidative stress induced by $\mathrm{H}_{2} \mathrm{O}_{2}$ activates the phosphorylation of ERK1/2 signaling protein in many neuronal 
studies that leads to apoptosis of the cells. In primary cortical cells, $\mathrm{H}_{2} \mathrm{O}_{2}$ was reported to have activated both ERK1/ 2 and p-38 MAP kinase signaling protein in a concentration and time dependent manner [49]. Studies on plant bioactives such as kukoamine B and loganin in human neuroblastoma ShSy5y cells, have been reported to provide neuroprotection against $\mathrm{H}_{2} \mathrm{O}_{2}$ induced oxidative stress via attenuation of phospho-ERK1/2 [50, 51]. Some earlier studies in differentiated and undifferentiated Shsy5y cells have shown that treatment with $\mathrm{H}_{2} \mathrm{O}_{2}$ increased the phosphorylation of ERK1/2 in a time and concentration dependent manner (up to $1.25 \mathrm{mM} \mathrm{H}_{2} \mathrm{O}_{2}$ ) where it increased as the concentration of $\mathrm{H}_{2} \mathrm{O}_{2}$. This activation of ERK1/2 leads to the neuronal cell death via apoptosis [52]. In concordance to that, our study demonstrated that PTE pre-treatment prior to $\mathrm{H}_{2} \mathrm{O}_{2}$ injury to cells protected the dIMR32 cells by attenuating the activation of ERK1/2.

\section{Conclusion}

In this study, it was established that the ethanolic extract of Peltophorum pterocarpum (PTE) did not exhibit cytotoxicity towards neuronally differentiated IMR32 cells (dIMR32) and only induced minimal apoptosis in the cells. PTE also exhibited neuroprotection in dIMR32 cells by ameliorating oxidative stress and apoptosis induced by $\mathrm{H}_{2} \mathrm{O}_{2}$ in a dose-dependent manner. This neuroprotection was achieved by increasing the mitochondrial membrane potential (MMP) and by attenuating the production of ROS in a dose dependent manner. However, PTE failed to reduce the caspase 3 activity suggesting caspase independent neuroprotection by PTE. Studies on the MAPKs pathway revealed that PTE was protective in dIMR32 cells by inhibiting the activation of stress activated p38 and by attenuating the phosphorylation of ERK1/2 and showed a decreasing trend in the activation of JNK. The results suggest that PTE can be further explored as an alternative preventive therapeutics for neurodegenerative diseases.

\footnotetext{
Abbreviations

5BrdU: 5-bromodeoxyuridine; ChAT: Choline acetyltransferase; DCFDA: 2',7'dichlorodihydrofluorescein diacetate; dIMR32: Differentiated neuroblastoma IMR32 cells; ERK: Extracellular signal-regulated kinase; $\mathrm{H}_{2} \mathrm{O}_{2}$ : Hydrogen peroxide; ICC: Immunocytochemistry;

JC1: Tetraethylbenzimidazolylcarbocyanine iodide; JNK: c-Jun N-terminal kinases; MAPK: Mitogen activated protein kinases; MMP: Mitochondrial membrane potential; MTT: 3-(4,5-dimethylthiazol-2-yl)-2,5-diphenyltetrazolium bromide; PTE: Ethanolic extract of Peltophorum pterocarpum leaf; ROS: Reactive oxygen species
}

\section{Acknowledgments}

The authors gratefully acknowledge the Ministry of Science and Technology Innovation (MOSTI) Malaysia for the research grant (No: 02-03-02-SF0130).

The authors also wish to thank Dr. Yeap Swee Keong in assisting in the use of the Flow Cytometry.

\section{Authors' contributions}

TM proposed the ideas, planned the experimental methods, carried out the cell based assays, analyzed the data and wrote the manuscript, TM and TS also collected the samples and carried out the extraction process and the
HPLC analysis. NN and RR also contributed to the idea conception, reviewed the manuscript and gave approval for the manuscript. All authors read and approved the final manuscript.

\section{Competing interests}

The authors declare that they have no competing interests.

\section{Publisher's Note}

Springer Nature remains neutral with regard to jurisdictional claims in published maps and institutional affiliations.

\section{Author details}

${ }^{1}$ SIRIM Bhd, Industrial Biotechnology Research Centre (IBRC), No 1, Persiaran Dato Menteri Seksyen 2, 40700 Shah Alam, Selangor, Malaysia. ${ }^{2}$ Genetics \& Regenerative Medicine Research Centre, Faculty of Medicine \& Health Sciences, Universiti Putra Malaysia, 43400 Serdang, Selangor, Malaysia. ${ }^{3}$ MAKNA-Cancer Research Laboratory, Institute Bioscience (IBS), Universiti Putra Malaysia, 43400 Serdang, Selangor, Malaysia.

Received: 10 May 2017 Accepted: 4 August 2017

Published online: 12 September 2017

\section{References}

1. Uttara B, Singh AV, Zamboni P, Mahajan RT. Oxidative stress and neurodegenerative diseases: a review of upstream and downstream antioxidant therapeutic options. Curr Neuropharmacol. 2009;7(1):65-74.

2. Halliwell B, Gutteridge J. Cellular response to oxidative stress: adaptation, damage, repair, senescence and death. In: Free radical in biology and medicine. 4th ed. Oxford: Oxford University Press; 2007. p. 187-267.

3. Yang F, Lim GP, Begum AN, Ubeda OJ, Simmons MR, Ambeguokar SS, Chen $P$, Kajed R, Glabe CG, Frautschy SA, Cole GM. Curcumin inhibits formation of amyloid beta oligomers and fibrils, binds plaques, and reduces amyloid in vivo. J Biol Chem. 2005;280(7):5892-901.

4. Ye J, Zhang Y. Curcumin protects against intracellular amyloid toxicity in rat primary neurons. Int J Clin Exp Med. 2012;5(1):44-9.

5. Damar U, Gersner R, Johnstone JT, Schachter S, Rotenberg A. Huperzine A as a neuroprotective and antiepileptic drug: a review of preclinical research. Expert Rev Neurother. 2016;16(6):671-80.

6. Shi C, Liu J, Wu F, Yew DT. Ginkgo biloba extract in Alzheimer's disease: from action mechanisms to medical practice. Int J Mol Sci. 2010;11(1):107-23.

7. Biswas K, Kumar A, Babaria BA, Prabhu K, Setty SR. Hepatoprotective effect of leaves of Peltophorum pterocarpum against paracetamol Induced acute liver damage in rats. J Basic Clin Pharm. 2009;1(1):10-5.

8. Sridharamurthy NB, Ashok B, Yogananda R. Evaluation of Antioxidant and Acetyl Cholinesterase inhibitory activity of Peltophorum pterocarpum in Scopolamine treated rats. Int J Drug Dev Res. 2012;4(3):115-27.

9. Manaharan T, Teng LL, Appleton D, Ming CH, Masilamani T, Palanisamy UD. Antioxidant and antiglycemic potential of Peltophorum pterocarpum plant parts. Food Chem. 2011;129(4):1355-61.

10. Borutaite $V$, Brown GC. Caspases are reversibly inactivated by hydrogen peroxide. FEBS Lett. 2001;500(3):114-8.

11. Polster BM, Fiskum G. Mitochondrial mechanisms of neural cell apoptosis. J Neurochem. 2004;90(6):1281-9.

12. Ono K, Han J. The p38 signal transduction pathway: activation and function. Cell Signal. 2000;12:1-13.

13. Strauss WL, Kemper RR, Jayakar P, Kong CF, Hersh LB, Hilt DC, Rabin M. Human choline acetyltransferase gene maps to region 10q11-q22.2 by in situ hybridization. Genomics. 1991;9(2):396-8.

14. Resende RR, Adhikari AA. Cholinergic receptor pathways involved in apoptosis, cell proliferation and neuronal differentiation. Cell Commun Signal. 2009;7:20.

15. Jash SK, Singh RK, Majhi S, Sarkar A, Gorai D. Peltophorum pterocarpum: chemical and pharmacological aspects. Int J Pharm Sci Res. 2014;5(1):26-36.

16. Whittermore ER, Loo DT, Watt JA, Cotman CW. Peroxide-induced cell death in primary neuronal culture. Neuroscience. 1995;67(4):921-32.

17. Gulden M, Jess A, Kammann J, Maser E\& Seibert H. Cytotoxic potency of $\mathrm{H}_{2} \mathrm{O}_{2}$ in cell cultures: Impact of cell concentration and exposure time. Free Radic Biol Med. 2010;49(8):1298-305.

18. Vermes I, Haanen C, Nakken HS, Reutelingserger C. A novel assay for apoptosis flow cytometric detection of phosphatidylserine expression on 
early apoptotic cells using fluorescein labelled Annexin V. J Immunol Methods. 1995;184(95):39-51.

19. Shaykhalishahi $\mathrm{H}$, Yazdanparast $\mathrm{R}, \mathrm{Ha} \mathrm{HH}$, Chang $\mathrm{YT}$. Inhibition of $\mathrm{H}_{2} \mathrm{O}_{2}$ induced neuroblastoma cell cytotoxicity by a triazine derivative, AA3E2. Eur J Pharmacol. 2009;622(1-3):1-6.

20. Wang $X Y, \mathrm{He} P Y, \mathrm{Du} J$, Zhang JZ. Quercetin in combating $\mathrm{H}_{2} \mathrm{O}_{2}$ induced early cell apoptosis and mitochondrial damage to normal human keratinocytes. Chin Med J. 2010;123(5):532-6.

21. Jiang B, Liu JH, Bao Y, An LJ. Hydrogen peroxide-induced apoptosis in PC12 cells and the protective effect of puerarin. Cell Biol Int. 2003;27(12):1025-31.

22. Sanchana M, Flaskas J, Hargreaves AJ. In vitro biomarkers of developmental neurotoxicity. In: Gupta RC, editors. Reproductive and Developmental Toxicology. 1st ed. Elsevier; 2011: Chapter 19, $227-252$.

23. Sattayasai J, Chaonapan P, Arkaravichie T, Saimpornkul R, Junnu S, Charoensilp P, Samar J, Jantaravinid J, Masaratara P, Suktitipat B, Manissorn $J$, Thongboonkerd V, Neungtom N, Moongkarndi P. Protective effects of mangosteen extract on $\mathrm{H}_{2} \mathrm{O}_{2}$-induced cytotoxicity in SK-N-SH cells and scopolamine-induced memory impairment in mice. PLoS One. 2013;8(12), e85053: 1-13.

24. Son YO, Jang YS, Heo JS, Chang WT, Choi KC Lee JC. Apoptosis inducing factor plays a critical role in caspase independent, pyknotic cell death in hydrogen peroxide exposed cells. Apoptosis. 2009;14:796-808.

25. Hampton MB, Orrenius S. Dual regulation of caspase activity by hydrogen peroxide: Implications for apoptosis. FEBS Lett. 1997;414(3):552-6.

26. Kim DK, Cho ES, Um HD. Caspase-dependent and -independent events in apoptosis induced by hydrogen peroxide. Exp Cell Res. 2000;257(1):82-8.

27. Ly JD, Grubb D, Lawen A. The mitochondrial membrane potential (DYm) in apoptosis; an update. Apoptosis. 2003;8:115-28.

28. Armenta MM, Ruiz CN, Rebollar DJ, Martinez E, Gomex PY. Oxidative stress associated with neuronal apoptosis in experimental models of epilepsy. Oxidative Med Cell Longev. 2014;2014:1-12.

29. Halliwell B, Clement MV, Ramalingam J, Long LH. Hydrogen peroxide. Ubiquitous in cell culture and in vivo? IUBMB Life. 2000;50(4-5):251-7.

30. Babich H, Liebling EJ, Burger RF, Zuckerbraun HL, Schuck AG. Choice of DMEM, formulated with or without pyruvate, plays an important role in assessing the in vitro cytotoxicity of oxidants and prooxidant nutraceuticals. In Vitro Cell Dev Biol Anim. 2009;45(5-6):226-33.

31. Kelts JL, Cali JJ, Duellman SJ, Shultz J. Altered cytotoxicity of ROS-inducing compounds by sodium pyruvate in cell culture medium depends on the location of ROS generation. Spring. 2015;4:269.

32. Long LH, Clement MV, Halliwell B. Artifacts in cell culture: rapid generation of hydrogen peroxide on addition of (-)-epigallocatechin,

(-)-epigallocatechin gallate, (+)-catechin, and quercetin to commonly used cell culture media. Biochem Biophys Res Commun. 2000;273(1):50-3.

33. Halliwell B. Are polyphenols antioxidants or pro-oxidants? What do we learn from cell culture and in vivo studies? Arch Biochem Biophys. 2008;476(2):107-12.

34. Long LH, Halliwell B. The effects of oxaloacetate on hydrogen peroxide generation from ascorbate and epigallocatechin gallate in cell culture media: Potential for altering cell metabolism. Biochem Biophys Res Commun. 2011;406(1):20-4

35. Chen L, Liu L, Yin J, Luo Y, Huang S. Hydrogen peroxide-induced neuronal apoptosis is associated with inhibition of protein phosphatase 2A and 5 leading to activation of MAPK pathway. Int J Biochem Cell Biol. 2009:41: 1284-95.

36. Li Z, Theus MH, Wei L. Role of ERK 1/2 signaling in neuronal differentiation of cultured embryonic stem cells. Develop Growth Differ. 2006;48(8):513-23.

37. Sun Y, Liu W, Liu T, Feng $X$, Yang N, Zhou HF. Signaling pathway of MAPK / ERK in cell proliferation, differentiation, migration, senescence and apoptosis. J Recept Signal Transduct. 2015;9893(February):1-5.

38. English JD, Sweatt JD. Activation of p42 Mitogen- activated Protein Kinase in Hippocampal Long Term Potentiation. J Biol Chem. 1996; 271(October 4):24329-32.

39. Pearson G, Robinson F, Gibson TB, Xu BE, Karandikar M, Berman K, Cobb M. Mitogen-Activated Protein (MAP) Kinase Pathways: Regulation and Physiological Functions. Endocr Rev. 2001;22(2):153-83. doi:10.1210/er.22.2.153.

40. Sweatt JD. The neuronal MAP kinase cascade: a biochemical signal integration system subserving synaptic plasticity and memory. J Neurochem. 2001;76(1):1-10.

41. Marshall C. Specificity of receptor tyrosine kinase signaling: transient versus sustained extracellular signal-regulated kinase activation. Cell. 1995;80(2):179-85.
42. Glotin AL, Calipel A, Brossas JY, Faussat AM, Tréton J, Mascarelli F. Sustained versus transient ERK1/2 signaling underlies the anti- and proapoptotic effects of oxidative stress in human RPE cells. Investig Ophthalmol Vis Sci. 2006:47(10):4614-23.

43. Spencer JPE. The interactions of flavonoids within neuronal signalling pathways. Genes Nutr. 2007;2(3):257-73.

44. Vauzour D, Vafeiadou K, Rodriguez-Mateos A, Rendeiro C, Spencer JPE. The neuroprotective potential of flavonoids: a multiplicity of effects. Genes Nutr. 2008;3(3-4):115-26.

45. Mansuri ML, Parihar P, Solanki I, Parihar MS. Flavonoids in modulation of cell survival signalling pathways. Genes Nutr. 2014;9(3):400.

46. Takeda K, Ichiijo H. Neuronal p38 MAPK signalling: An emerging regulator of cell fate and function in the nervous system. Genes Cells. 2002;7(11):1099-111.

47. Crossthwaite AJ, Hasan S, William R. Hydrogen peroxide-mediated phosphorylation of ERK1/2, AKt/PKB and JNK in cortical neurones: Dependence on $\mathrm{Ca}^{2+}$ and PI3-kinase. J Neurochem. 2002;80(1):24-35.

48. Luo $Y$, DeFranco DB. Opposing roles for ERK1/2 in neuronal oxidative toxicity: Distinct mechanisms of ERK1/2 action at early versus late phases of oxidative stress. J Biol Chem. 2006;281:16436-42.

49. Odaka H, Numakawa T, Adachi N, Ooshima Y, Nakajima S, Katanuma Y, Inoue T, Kanugi $\mathrm{H}$. Cabergoline, dopamine D2 receptor agonist, prevents neuronal cell death under oxidative stress via reducing excitotoxicity. PLoS One. 2014;9(6):1-11.

50. Kwon SH, Kim JA, Hong SI, Jung YH, Kim HC, Lee SY, Jang CG. Loganin protects against hydrogen peroxide-induced apoptosis by inhibiting phosphorylation of JNK, p38, and ERK 1/2 MAPKs in SH-SY5Y cells. Neurochem Int. 2011;58(4):533-41.

51. Hu XL, Niu YX, Zhang Q, Tian X, Gao LY, Guo LP, Meng WH, Zhao QC Neuroprotective effects of Kukoamine $B$ against hydrogen peroxide-induced apoptosis and potential mechanisms in SH-SY5Y cells. Environ Toxicol Pharmacol. 2015:40(1):230-40.

52. Ruffels J, Griffin M, Dickenson JM. Activation of ERK1/2, JNK and PKB by hydrogen peroxide in human SH-SY5Y neuroblastoma cells: role of ERK1/2 in $\mathrm{H}_{2} \mathrm{O}_{2}$-induced cell death. Eur J Pharmacol. 2004;483(2-3):163-73.

\section{Submit your manuscript to a SpringerOpen ${ }^{\circ}$ journal and benefit from:}

- Convenient online submission

- Rigorous peer review

- Open access: articles freely available online

- High visibility within the field

- Retaining the copyright to your article

Submit your next manuscript at $>$ springeropen.com 